\title{
The Introduction of School Library Coordinators to Assist Teacher Librarians: A Grass-roots Challenge for Local
}

Government in Japan

\author{
Kazuko MASUDA, Library, Information and Media Studies, \\ Graduate School, the University of Tsukuba, Japan
}

\begin{abstract}
This paper discusses the role of the School Library Coordinator, a post created by Kawasaki City, Japan local government, in accordance with the legislated introduction of teacher librarians into all Japanese schools. It is difficult for teacher librarians to play the roles of both teacher and librarian simultaneously. They are expected to play the central role in school libraries, to support pupils' spontaneous learning activities as well as to foster pupils' imaginative minds.Teacher librarians are also expected to coordinate schools, families and communities to promote pupils' reading activity by the Basic Plan to Promote Children's Reading Activity. Kawasaki City local government introduced School Library Coordinators to assist teacher librarians and to complement their onerous duties in schools and society. Although this paper's research and analysis indicates that Kawasaki City's innovation of School Library Coordinators has been successful, it is noted that there is potential for more efficient performance by library coordinators in collaboration with teacher librarians.
\end{abstract}

\section{Legislated Introduction of Teacher Librarians in Japan}

In Japan, the School Library Law amended in June 1997 provides that all the schools with 12 classes or more must assign teacher librarians from the beginning of April 2003. Although the School Library Law was promulgated in 1953, it prescribed schools might not have teacher librarians for a while. Therefore there have been few teacher librarians more than 50 years. Japanese government reported that almost schools assigned teacher librarians by April 2003 (Ministry of Education, Culture, Sports, Science and Technology, 2004).

\section{Professional Roles of Teacher librarians in Japan}

\section{Qualification System of Teacher Librarians}

Recently, Japanese government confirmed the necessity of legislated introduction of teacher librarians even under the overall policy revision of deregulation. As a result of the reviews, Japanese government concluded that a teacher librarian plays professional roles in a school library and that its qualification system is essential for the development of school library.

To become a teacher librarian in Japan, not only must you complete the entire subject requested by the School Library Law, but also you must hold a teacher certificate. 
At present, all the teacher librarians assigned in elementary schools in Japan hold a teacher's position concurrently, and most teacher librarians must work for their school libraries without any reduction of duty as a teacher (Japan School library Association, 2004).

\section{Purpose of School Libraries}

According to the School Library Law, the purpose of a school library is provided that it should contribute to developing school curriculum and fostering pupils' education as a facility of a school. A school library is expected to serve pupils and teachers by the following ways;

1 To collect books and materials for a school library, and to serve for pupils' and teachers' use,

2 To classify collections properly, and to maintain catalogs,

3 To hold reading activities, workshops, shows, exhibitions, etc,

4 To guide pupils to use library collections, and

5 To communicate and cooperate with other school libraries, public libraries, museums, community centers, etc.

\section{Seven Roles of a Teacher Librarian}

The roles of teacher librarians are generally regarded as the professional functions for school libraries with five ways of services stated above. As a school library comes to play a main role as a media center in a school, more functions are expected. The Japan School Library Association, therefore, proposed to add two professional functions to the legislated roles of school libraries. The Japan School Library Association (1983) put two additional functions of school libraries.

1 To make plans of whole school library services, and library use and reading instruction, and

2 To assist classroom teachers to do information use and reading instruction.

\section{Categorizing Seven Roles into Four Activities of a School Library}

As stated above, the roles of teacher librarians are quite divers. Some guidebooks for school libraries indicate almost the same categorization of teacher librarian's roles (Japan School library Association, 2000; Watanabe, 1999). They show four categories, which consist of management activities, technical activities, direct library services activities and instructional activities. Figure 1 shows some examples of activities by each of the four categories .

Figure1: Four Categories and Activities of a School Library

\begin{tabular}{|l|l|}
\hline Four Categories & Examples of Activities
\end{tabular}




\begin{tabular}{|l|l|}
\hline Management Activities & Assessment and improvement of school library \\
& Statistics and analysis of total library services \\
& Making rules for library use \\
& Coordination between teachers \\
& Training for other teachers \\
Budget management for school library
\end{tabular}

\section{Government Policy around Teacher Librarians}

\section{Cooperation with Community Volunteers and Librarians in Public Libraries}

A recent government policy, the Basic Plan for the Promotion of Children's Reading Activities in August 2002, encourage a teacher librarian to perform professional roles by cooperating with community volunteers, librarians in public libraries, other teachers and staff of a school. Since teacher librarians are expected to perform their professional roles efficiently, their cooperation with community volunteers is also expected in Japan.

\section{Key Roles of Local Governments}

Teacher librarians are expected to perform the four major activities to make school libraries to attain the purposes in cooperation with related people. How teacher librarians should cooperate with other teachers, librarians in public schools and community volunteers fully depends on each local educational board.

Japanese government recommends two major ways for local governments to utilize teacher librarians with others. One is to reduce some school duties, and to give them some time to concentrate as teacher librarians. Another is to cooperate with community volunteers and librarians in public libraries to perform the roles of school libraries.

In choosing either way, every local educational board should prioritize the 
activities of teacher librarians depending on the environment of school libraries, and make some effective arrangement to secure the function of school libraries. It is the local government that has a key to make the most of school libraries and teacher librarians.

\section{Kawasaki City and its Board of Education}

\section{Kawasaki City, a Local Government Responsible for its Primary Education}

Kawasaki City has its population of over 1.3milion. It is one of the large satellite cities around the capital city of Tokyo. Since Kawasaki City is one of the designated cities by the ordinance of the Local Autonomy Law, its educational board is entitled to appoint and dismiss its teachers and to decide its pay structure unlike other cities.

It can be said that Kawasaki City is a minimum administration unit of the national education system in Japan, and is worth researching to promote school library activities and enhance teacher librarian's performances.

There are 114 public elementary schools, and one percent of pupils in Japan has its education under the Kawasaki City Board of Education.

\section{Relatively Well-Advanced Equipment of School Libraries in Kawasaki City}

Before studying the situation of teacher librarians and its supporting system in Kawasaki City, it is worth reviewing the environment related with school libraries.

\section{- Primary School Libraries Equipped with the OPAC}

The information technology is broadly introduced in the school libraries in primary schools in Kawasaki City. The Online Public Access Catalog (OPAC) was installed in about $72 \%$ of the primary schools in Kawasaki City by March 2004 compared with the national average of the installation of the OPAC about $23 \%$.

The relatively advanced introduction of the OPAC may affect the required ability and the performance of teacher librarian's duties. It seems interesting to observe the school libraries equipped with the OPAC. The catalog data retrieved by the OPAC systems are administrated by a local public library.

\section{- Budget Appropriation for Collections}

The budget for collections at a school library in Kawasaki City has been appropriated more than that of the average in Japan. Kawasaki City spends 1.7 times as much as the national average does.

\section{- Collection in School Libraries}

Japanese government shows the standard numbers of books, which should be collected in school libraries according to the total number of classes of the schools. 
About $95 \%$ of the primary schools in Kawasaki City have the collections of books, which satisfy the standard numbers compared with about $35 \%$ of those in Japan.

\section{- Groups of Community Volunteers}

Some groups of community volunteers participate in the school library activities for about $91 \%$ of the primary schools in Kawasaki City compared with about $33 \%$ in Japan. The groups of community volunteers actively support the library programs at primary schools in Kawasaki City trough circulation counter services, book arrangements on the shelves and story telling.

\section{- All Elementary School Libraries with Teacher Librarians}

Regardless of the number of the classes in a school, teacher librarians are assigned for about $55 \%$ of all primary schools in Japan. In Kawasaki City, however, about $96 \%$ of primary schools have teacher librarians although all schools are not necessary required to introduce teacher librarians (2004a). But there is no full-time teacher librarian even in Kawasaki City. Although Japanese government formerly allowed local educational authorities to review and reduce some duties for teacher librarians, only four out of 110 teacher librarians in Kawasaki City are allowed to have some exclusive time to concentrate on their school library work.

Figure2: Equipment of School Libraries in Kawasaki City and All Japan

\begin{tabular}{|l|c|c|}
\hline & Kawasaki & Japan \\
\hline Introduction of the OPAC & $100.0 \%$ & $23.4 \%$ \\
\hline $\begin{array}{l}\text { Annual expense for books and others information media par } \\
\text { school }\end{array}$ & $757000 \mathrm{yen}$ & $439000 \mathrm{yen}$ \\
\hline Achievement rate for the number of books collections & $95.0 \%$ & $34.8 \%$ \\
\hline Volunteers working for school libraries & $91.2 \%$ & $32.5 \%$ \\
\hline Placement Teacher Librarians & $96.0 \%$ & $54.6 \%$ \\
\hline
\end{tabular}

(Ministry of Education, Culture, Sports, Science and Technology, 2004; Japan School Library Association, 2003).

\section{Introducing a New Supporting System for Teacher Librarians}

\section{Appointing School Library Coordinators}

Although teacher librarians were appointed to all the elementary schools in Kawasaki City, its board of education recognized that most teacher librarians could not manage their school libraries by themselves and could not play full professional roles as expected according to the previous studies and experiences. It is not enough to appoint teacher librarians in all schools in order to complement their onerous duties in their schools and local society. Although the Kawasaki City realized that its school libraries needed some additional personnel, the local government could not afford to employ more person for the every school library.

The Kawasaki City Board of Education decided to introduce a new supporting 
system for teacher librarians in April 2003. This system is an original attempt to utilize teacher librarians. Since the new system has started two years ago, Kawasaki City is now under the way to find how its supporting system works well.

\section{School Library Coordinators and Teacher Librarians}

\section{Purpose of Studying in Kawasaki City}

The roles of teacher librarians are regarded as professional duties in Japan. Unfortunately, however, teacher librarians are not regarded as important in the scene of school education because of their long absence in history. Even though the School Library Law enhanced the appointment of teacher librarians in all the schools in Kawasaki, teacher librarians still do not have sufficient environment to perform their professional roles. Producing better environment for teacher librarians to perform their professional roles is significantly important. Therefore, Kawasaki City introduced supporting system as one of the practical experiments to make better environment for teacher librarians. It is necessary to know how School Library Coordinators support teacher librarians.

The purpose of studying this new supporting system for teacher librarians is;

- To know what kind of roles teacher librarians actually perform under the supporting system,

- To know what kind of roles other personnel share with teacher librarians under the supporting system, and

- To know how School Library Coordinators help teacher librarians and others in school libraries.

\section{Data Acquired by the Reports, Observation and Interviews}

Investigation has been done to know what teacher librarians and community volunteers and librarians in public libraries do for school libraries. And it was also examined to know how School Library Coordinators work for arranging the roles between teacher librarians, community volunteers for contributing school libraries and librarians in public libraries.

The study was focused on the school libraries of the primary schools in Kawasaki City. The activities by each participant were categorized in four categories of major roles of teacher librarians.

\section{- By Written Reports}

For the investigation into the actual condition of all elementary school libraries, the author mainly used the reports written by School Library Coordinators, and interviewed them informally. These reports are submitted once a year by all schools. This paper investigated the reports for two years.

\section{- By Observation and Interviews}


To get supplementary information to understand the actual activities in the school libraries, the author made a participating observation at one of the primary schools in Kawasaki City.

The author was admitted to stay in the school library any time. The primary school observed has almost average numbers of classes and teachers in Kawasaki. And the observed school with seventeen classes is included in the standard size of the primary schools defined by Japanese government.

The author observed every Thursday, and stayed in the school library totally 24 times in 2004. Each times of the observation, the author recorded the behaviors of the teacher librarians, other teachers and the pupils in the research note.

The author also attended a pupil's selective curricular activities on the school library and observed how the teacher librarian instructs the pupils. The author interviewed the teacher librarian. The interview was open-ended question, and the author asked to talk freely about her experience as a teacher librarian. The teacher librarian was found appointed 2 years ago, and acquired its qualification about 20 years ago. She never worked for school library before appointed, although she is an experienced teacher.

In addition to the observation and hearing of the teacher librarian, the author attended the meetings of the School Library Coordinators and the workshops of the community volunteers in order to study the whole system of the school libraries with the School Library Coordinators.

\section{Roles of School Library Coordinators}

The roles of School Library Coordinators are in a word to connect school libraries to community volunteers, to advice teacher librarians and to improve all school libraries in Kawasaki City (Kawasaki City Board of Education, 2004b). As each School Library Coordinator goes the round of schools in charge and advices them to improve their situation of school libraries' activities, collections, collaborations in classrooms and so on, all the school libraries in Kawasaki City improve finally to attain its purpose legislated in the School Library Law and mission planned by promotion plans.

The conceptual illustration of the supporting system for teacher librarians is shown in Figure 3.

The most important function for the School Library Coordinators is to orchestrate all related persons in the school libraries appropriately.

Figure3: Conceptual illustration of the supporting system for teacher librarians

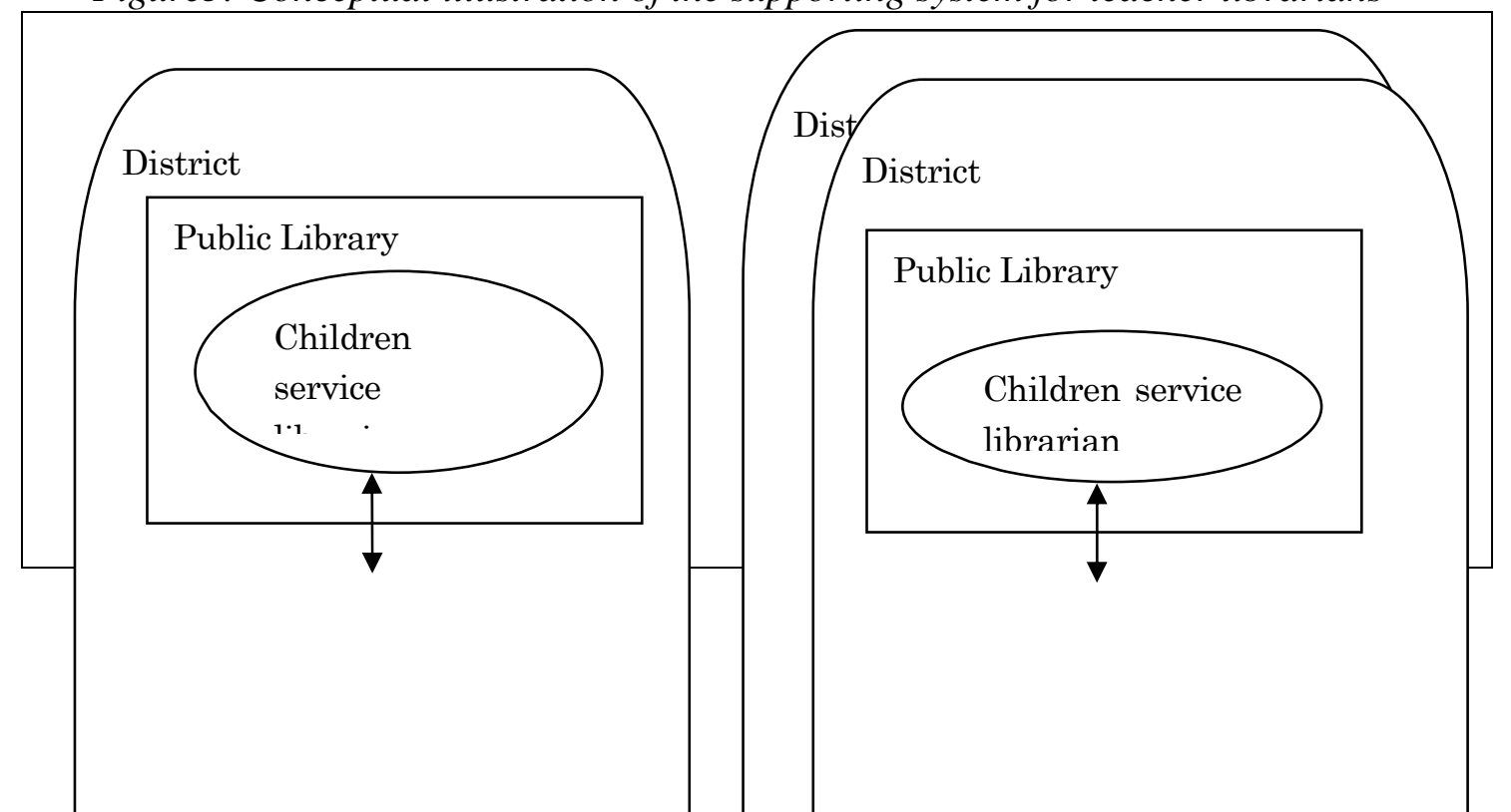




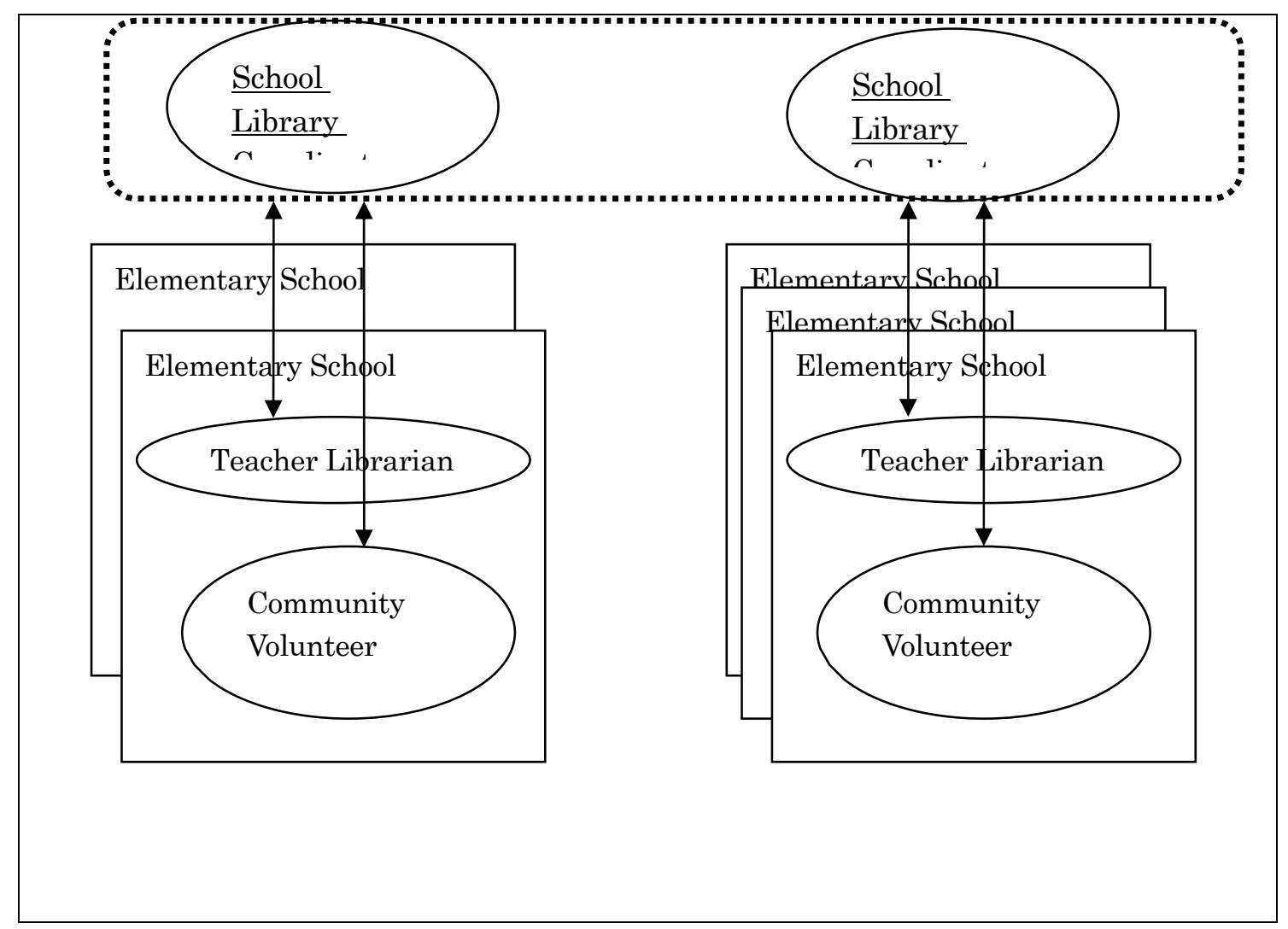

The specific roles of the School Library Coordinators are as follows.

- To coordinate the necessary activities for the school library with the teacher librarian, the community volunteers and the librarians in public libraries.

- To help and foster teacher librarians who do not have sufficient time and their skills

- To make the most of the community volunteers.

- To improve quality of the teacher librarians and the community volunteers.

- To report the condition and the activities of the school libraries in every school once a year to the board of education.

- To counsel the board of education on the training plans for teacher librarians.

- To share the information on the school libraries among the teacher librarians, the community volunteers and librarians in public libraries by issuing newsletters and holding workshops.

\section{Members of School Library Coordinators}

The Kawasaki City Board of Education assigns its School Library Coordinators as part-time officials.

There are ten School Library Coordinators now and their backgrounds consist of 
experienced teachers, community volunteers and librarians. The members have to some extent balanced professional skills as both teachers and librarians, although the Kawasaki City Board of Education did not impose any requirement of qualifications to assign its School Library Coordinators.

Figure4: Members of the School Library Coordinator

\begin{tabular}{|c|c|c|}
\hline Area & $\begin{array}{c}\text { Number } \\
\text { of } \\
\text { schools } \\
\text { in charge }\end{array}$ & Background of School Library Coordinators (Year 2004) \\
\hline A & 25 & Veteran teacher with experience of school library services \\
\hline B & 25 & Veteran teacher with experience of school library services \\
\hline C & 23 & Veteran teacher with experience of school library services \\
\hline D & 26 & Veteran teacher with experience of school library services \\
\hline \multirow{2}{*}{ E } & 24 & Librarian with experience in a public library \\
\cline { 3 - 4 } & 21 & Community volunteer with experience of school library services \\
\cline { 3 - 3 } F & \multirow{2}{*}{24} & Community volunteer with experience of school library services \\
\cline { 2 - 3 } G & \multirow{2}{*}{24 Community volunteer with experience of school library services } \\
\hline
\end{tabular}

\section{Expected Roles for Teacher Librarians, Community Volunteers and}

\section{Librarians in Public Libraries}

In order to recognize how all the duties in the school libraries are shared and supported by librarians, the community volunteers and the librarians in public libraries, the idea of four categories of the school library's activities. It seems quite useful to understand how Kawasaki City assigns and expect the activities of school libraries to the related persons, i.e. teacher librarians, community volunteers and librarians in public libraries into the four categories of the professional roles of teacher librarians.

The author composed and presented the activities of teacher librarians, community volunteers and librarians in public libraries by the degrees of expectation.

\section{- Expected Activities for Teacher Librarians}

Under this system with School Library Coordinators, teacher librarians are still expected to work as the core of professional roles in each school library. Teacher librarians should basically cover all the four categories. The instructional activities are most expected for teacher librarians. Teacher librarians should instruct pupils to become independent learners by using various information media including the latest information technology. Although community volunteers can also be expected to share some instructional activities, only teacher librarians can be responsible for the management activities.

\section{- Expected Activities for Community Volunteers}

Community volunteers are expected to work for a kind of daily and routine tasks 
such as story telling, arranging books on the shelves, providing counter services, copy cataloging and selecting books in each school libraries. Community volunteers are supposed to share some technical activities, direct services activities and instructional activities of the four categories depending on their capacity and skills. their ability.

School Library Coordinators are expected to help these volunteers to develop

\section{- Expected Activities for Libraries in Public Libraries}

Librarians in public libraries are expected to provide their library technical skills and materials in public libraries with teacher librarians for school libraries. Librarians in public libraries are expected to cover some technical and direct service activities.

Figure5: The Expected Roles of Teacher librarians, Community Volunteers and Librarians in public libraries

\begin{tabular}{|l|c|c|c|c|}
\hline & $\begin{array}{c}\text { Management } \\
\text { Activities }\end{array}$ & $\begin{array}{c}\text { Technical } \\
\text { Activities }\end{array}$ & $\begin{array}{c}\text { Direct } \\
\text { Service } \\
\text { Activities }\end{array}$ & $\begin{array}{c}\text { Instructional } \\
\text { Activities }\end{array}$ \\
\hline Teacher Librarians & $\bigcirc$ & $\triangle$ & $\triangle$ & $\bigcirc$ \\
\hline Community Volunteers & & $\bigcirc$ & $\bigcirc$ & $\bigcirc$ \\
\hline $\begin{array}{l}\text { Librarians in public } \\
\text { libraries }\end{array}$ & $\bigcirc$ & $\bigcirc$ & \\
\hline
\end{tabular}

(o): The category must be covered by the related person,

$\bigcirc$ : The category is expected to be covered by the related person,

$\triangle$ : The category may to some extent be covered by the related person,

Each symbol denotes the degree of expectation by the related persons in school libraries to the four categories of teacher librarian's roles.

\section{Results of the Case Study in Kawasaki}

\section{Teacher Librarians’ Behavior with School Library Coordinators}

The observation, survey and hearing founds that the teacher librarians in Kawasaki City take various actions compared with the four categories of activities of school libraries.

The average number of persons who are in charge of a school library is about three persons including one teacher librarian. The teacher librarian is mainly assigned to instructional activities for school library services.

\section{- Management Activities}

It is considered that the management of school libraries is the exclusive role only teacher librarian can cover.

Primary schools have the rules for their library use. A rule regulates when pupils can use school libraries which grade of pupils can use there and so on. 
Developing rules of library usage is teacher librarians’ role.

The School Library Coordinators may enhance the teacher librarians to develop the rules.

Teacher librarians plan and appropriate the school library budgets, and prepare for the school library equipment and collections within their budgets.

Teacher librarians also play a liaison role between teachers in their schools. For example, teacher librarians circulate the models of annual reading instruction plans for pupils developed by a study group of teachers. An annual reading plan includes a reading instruction plan and an information literacy instruction plan.

\section{- Technical Activities}

Some technical activities of teacher librarians are expected to be covered by the help of community volunteers, but teacher librarians still perform some technical activities such as the book arrangement on the shelves and the book orders assisted by teachers, pupils of library clubs and community volunteers.

School Library Coordinators indicate some book lists for school libraries according to their curriculum. The book lists might be useful for books selection for school libraries.

\section{- Direct Library Services Activities}

Teacher librarians provide counter services such as lending and receiving books. Teacher librarians help pupils search books but they do not feel that they have sufficient time to stay at school libraries. Teacher librarians do simple reference services such as telling book locations.

Some teacher librarians issue newsletters periodically to inform new and interesting collections in the school libraries.

\section{- Instructional Activities}

There are three types of instructional activities by teacher librarians. They guide pupil's selective curriculum activities working on the school library. And teacher librarians provide reading and information use instructions for pupils.

The selective curriculum activities of pupils take once a month for one hour. Teacher librarians teach pupils how to make bookshelves neat and to serve at circulation counter.

A teacher librarian who works for two hours in a week as a teacher librarian tells stories and instructs readings during the time. It is, however, hard for teacher librarians to find sufficient time for story telling, therefore teachers and community volunteers often provide story telling instead of teacher librarians.

Teacher librarians also explain an annual model plan for reading and information literacy instruction to other teachers. The information use instructions by teacher librarians observed mainly an orientation to use a school library. Teacher librarians plan to instruct the basic skills to use school libraries on each grade based on the rules developed by them. Some teacher librarians provide orientations as well as other teachers. 
Community volunteers performed various roles to cover a part of technical activities, direct services activities and instructional activities but management activities.

\section{- Technical Activities}

Community volunteers performed various technical activities. Community volunteers maintain the OPAC data for school libraries by copying the catalogs from public libraries. Some community volunteers make book lists for story telling, and arrange the books on the shelves. Community volunteers do select and weed out useless books instead of teacher librarians.

School Library Coordinators assist the community volunteers in selecting and weeding books.

\section{- Direct Library Service Activities}

Community volunteers can stay relatively longer at school libraries than teacher librarians, and have more chance to serve pupils at a school library counter. Community volunteers do simple reference services such as telling book locations. They also some issue newsletters to inform activities about volunteers and the new or interesting collections in the school libraries.

\section{- Instructional Activities}

Reading stories to pupils is found to be the most important activity for community volunteers. Community volunteers act on their own initiatives for reading instructions and selecting books for reading stories. Community volunteers sometimes communicate with classroom teachers about the theme of reading. Community volunteers also guide pupils for the use of the school library.

\section{Behavior of Librarians in Public Libraries}

Librarians in public libraries perform some technical and direct library service activities.

\section{- Technical Activities}

Public libraries donate the weeded books to school libraries and contribute to increase the collections of the school libraries. Community volunteers as a substitute for teacher librarians often come to select necessary books from weeded books in the public library. Teacher librarians are too busy to this kind of cooperation with public libraries.

Some librarians in public libraries make the book lists corresponding to the textbooks of primary schools. The book lists might be useful for the book selection and classroom lessons.

Librarians in public libraries also give some workshops of library skills to community volunteers.

\section{- Direct Library Service Activities}


Librarians in Public libraries support the resource-based learning for primary schools. Pupils come to public libraries and research their schoolwork as their classroom lesson there. Public libraries also provide book-lending services for a school. Teachers borrow books at public libraries without any assistance by teacher librarians.

\section{Studying the School Library Coordinators}

Based on the behavior of teacher librarians, community volunteers and librarians in public libraries compared with the four categories of the school library activities, this paper discusses how the School Library Coordinators support the professional teacher librarians, community volunteers and librarians in public libraries.

\section{Coordination Between Teacher librarians, Community Volunteers and}

\section{Librarians in Public Libraries}

In order to investigate the behavior and activities of the School Library Coordinators, each coordination of the between bilateral relationship is studied. There are three bilateral coordination between teacher librarians and community volunteers, between teacher librarians and librarians in public libraries, and between community volunteers and librarians in public libraries.

\section{- Coordination between Teacher Librarians and Community Volunteers}

School Library Coordinators contribute the cooperation between teacher librarians and community volunteers when schools introduce the OPAC system. School Library Coordinators advise community volunteers for their roles, and work with them to introduce the OPAC system into school libraries. As a result of the advices from School Library Coordinators to community volunteers, the room of school libraries became arranged better and its collection was improved. School Library Coordinators on behalf of busy teacher librarians utilize community volunteers for school libraries.

\section{- Coordination between Teacher Librarians and Librarians in Public Libraries}

School Library Coordinators develop some reference book lists corresponding to textbooks with assistance of librarians in public libraries. School Library Coordinators pick up some reference books for textbooks and ask librarians in public libraries to complete bibliographic data for the book lists. Teacher librarians can see the books mentioned in the textbooks and can use the lists for assistance of classroom lesson. It means that coordinators connected librarian's skills to teacher librarians.

\section{- Coordination between Community Volunteers and Librarians in Public Libraries}

School Library Coordinators connect the persons in charge of the OPAC of the school library system and community volunteers, when community volunteers are facing trouble with their maintenance of the OPAC. School Library Coordinators give referral information to community volunteers for helping their activities. 


\section{- The Other Coordination}

School Library Coordinators cooperated with booksellers who are not expected.

Booksellers classify and equip books. Coordinators require booksellers to classify and equip books appropriately instead of busy teacher librarians. School Library Coordinators tell teacher librarians about services, which booksellers can provide. Especially newly assigned teacher librarians can order book sellers to provide appropriate services.

\section{Achievement of School Library Coordinators}

School Library Coordinators Helped Teacher Librarians to Release Onerous Duties, and Activate School Libraries. School Library Coordinators on behalf of busy teacher librarians utilized potential volunteers for school libraries, improved environment of school libraries and assisted teacher librarian's onerous duties. School libraries are activated and improved significantly by the assistance of School Library Coordinators. They minimize the duties of teacher librarians, and to decentralize teacher librarian's paraprofessional duties into the persons who have more appropriate skills and time.

The introduction of School Library Coordinators contributed to develop the environment where teacher librarians could perform their professional roles more effectively. School Library Coordinators helped teacher librarians as follows;

- Decentralize teacher librarian's paraprofessional activities into the person who has appropriate skills

- Reduce the burden of teacher librarian's duties

- Improve ability of community volunteers to work for school libraries.

- Import librarian’s skills to school libraries in public libraries into school libraries.

- Provide objective data to teacher librarians to develop elementary school libraries.

\section{Conclusion and Further Development of Teacher Librarians with School Library Coordinators}

\section{Burden Sharing of Professional Roles for School Libraries}

The result of this study describes how school libraries are operated by teacher librarians, community volunteers and librarians in public libraries under the introduction of School Library Coordinators in Kawasaki City, along with the legislative assignment of teacher librarians in Japan. The functions school libraries should provide seem to perform better under the introduction of the School Library Coordinators because the result 
of this study shows that all the four major categories of activities supporting the school library functions are well covered with the activities performed by the teacher librarians, community volunteers and librarians in public libraries under the coordination and the complementary activities by School Library Coordinators. In other word, the teacher librarians can concentrate what they should do first as school libraries and can share some burden with the related persons in schools. School Library Coordinators promote the involvement of the community volunteers and the librarians in public libraries as well as they reduce and substitute some burden of teacher librarians for school libraries.

\section{Priorities of Teacher Librarians in School Libraries}

Although School Library Coordinators enhance to involve the community volunteers and the librarians in public libraries in school libraries, teacher librarians should still play the heart of the professional roles of school libraries.

Although all activities for school libraries seem to be shared and performed well by teacher librarians, community volunteers and librarians in public librarians at each primary school, there are some overlaps of the activities between teacher librarians and the other related persons. For example, teacher librarians and community volunteers depending on the primary schools provide such instructional activities like a story telling. The duplications of the activities by the related persons for school libraries imply that teacher librarians may perform paraprofessional roles as well as professional ones.

Further studies are expected to determine the better priorities of the professional roles for teacher librarians under the system with community volunteers, librarians in public libraries and School

Library Coordinators.

\section{Further Contribution by Teacher Librarians}

The most interesting result of this study comes to the background of the School Library Coordinators. The former teachers with the experience of school library services occupy $40 \%$, which implies that the teacher librarians may contribute to foster the pupils as the School Library Coordinators after they retire their positions in the schools in future. The experienced teacher librarians may contribute to develop more skilled the School Library Coordinators and more efficient orchestration for school libraries.

\section{Further Contribution by Community Volunteers Contribution}

This study also found that the community volunteers experienced in school libraries account $40 \%$ of the School Library Coordinators. It indicates that not only the professional backgrounds such as the experiences of teacher librarians and librarians in public libraries but also the experiences of the community volunteers are able to contribute to the school libraries more deeply and broadly as professional School Library Coordinators. Therefore, the introduction of the School Library Coordinators may broaden the further opportunities of community volunteers to participate in fostering pupils through the activities for school libraries. 


\section{Conclusion}

The introduction of School Library Coordinators seems to be successful enough to imply the possibility to spread other local educational authorities in Japan. Some experiences at school libraries as either a teacher librarian, a community volunteers or a librarian in a public library helps a School Library Coordinator connect the activities for school libraries to the related persons properly and work efficiently.

This paper, in addition, presented that School Library Coordinators are the key person to make the most of the professional roles of teacher librarians in Kawasaki City. The role sharing by School Library Coordinators, however, is crucial for teacher librarians to perform their professional roles because teacher librarians would like to concentrate to the professional roles rather than the paraprofessional roles in school libraries. Therefore, this study recommends the continuous research on the desirable sharing between professional and paraprofessional roles for teacher librarians. 


\section{References}

Japan School Library Association. (1983). The Amendment of School Library Law-The Issues and Foresight-. Tokyo: Japan School Library Association.

Japan School Library Association. (2000, June). The Manual for The Amendment for School Library Law: Future School Libraries and Teacher librarians’ Roles. Tokyo: Japan School Library Association.

Japan School Library Association. (2003, May). The Result of Investigation for the Placement of Teacher Librarians. Japan School Library Association. Retrieved February 26, 2005, form http://www.j-sla.or.jp/oshirase/2003haturei.html

Japan School Library Association. (2004, June). Research of Teacher Librarians at the Present Condition. School Library. 2005.1. No.651. p21

Ministry of Education, Culture, Sports, Science and Technology. (2004, February 25). The Result of Investigation for School Libraries. Retrieved February 3, 2005, from http://www.mext.go.jp/b_menu/houdou/16/02/04022501.htm

Kawasaki City Board of Education. (2004a). “The City of Reading”; The Plan to Promote Children's Reading Activity. Kawasaki City. Retrieved February 15, 2005, from http://www.city.kawasaki.jp/88/88syogai/home/keikaku/homepage1.html

Kawasaki City Board of Education. (2004b) The Guidebook for School Library. Kawasaki City.

Watanabe, Shigeo. (1999). The Roles for Teacher Librarians. Tokyo: Seikyu Co.

\section{Author Note}

Kazuko MASUDA, BA, MLIS, is in the doctoral program of the Library, Information and Media Studies in the University of Tsukuba, and is a former councilor of the committee of the Kawasaki Education Plan. She teaches at the Division of Social Information Studies in the Otsuma Women's University, and the Tsurumi University. 
Reproduced with permission of the copyright owner. Further reproduction prohibited without permission. 